\title{
Understanding Javanese Hybridity: A Study on Sanskrit and Arabic Influence in the Javanese Language
}

\author{
Anugrah Nur Ikhsan and Dwi Puspitorini \\ Universitas Indonesia, Indonesia \\ E-mail:dwi.puspitorini@ui.ac.id
}

\begin{abstract}
This study aims to examine the hybridity of Javanese culture as reflected in its linguistic hybridity, in order to prove the harmony between Javanese and foreign cultures. To this end, lexical and grammatical analysis was performed on Javanese linguistic units borrowed from Sanskrit and Arabic languages. This study is a qualitative study that uses data from two sources. To analyze the influence of Sanskrit in Javanese, the data was taken from a corpus of Old Javanese texts stored on http://sealang.net/ojed/, which then were processed using the corpus and collocates features available on the web page. Meanwhile, to observe Arabic influence in Javanese, the data was collected from a quite popular Javanese suluk (poetry), titled Suluk Wujil, which then were processed using the concordance feature in antcont app. The analysis reveals that a difference exists between the hybridity that occurred during the Old Javanese and Middle Javanese eras. Despite this difference, the hybridity in Javanese, which have been taking place for centuries, still shows a harmony between the Javanese culture and foreign cultures.
\end{abstract}

Keywords: Linguitic Hibridity; Javanese Language; Old javanese Language; Sanskrit influence, Arabic Influence

\section{INTRODUCTION}

In cultural studies, the notion of hybridity is often discussed in terms of its relation with issues of globalization, diasporic culture, and postcolonialism. In fact, the word hybrid has even declared as the word of the year in 2007 [1, p. 27]. In linguistics, the term hybrid refers to a complex word whose components are originated from different languages [1]. Javanese, for example, has the word ngepit 'to ride a bike' and bal-balan 'to play with a ball' of which the roots come from Dutch words fiets 'bike' and bal 'ball'. Both words are borrowed and undergo an affixation and reduplication, respectively. 
Linguistic hybridity has virtually been taking place throughout the lifetime of human civilization. Likewise, linguistic hybridity in Javanese has also been occurring for as long as the age of the language itself. Throughout the long history of the Javanese language, at least two foreign languages have marked their influences, namely Sanskrit (during the Old Javanese era, approximately in the 9th-15th century) and Arabic (during the Middle Javanese era, roughly in the 14 th -17 th century). Language contact between each of both languages and Javanese occurred, among others, in attempt to a spread certain religion to Java. The influence of Hindi culture in Old Javanese literature has resulted in the strong influence of Sanskrit in the Old Javanese language. As evidence, Gonda estimates that at least $25 \%-30 \%$ linguistic units in kakawin (a form of Old Javanese poetry composed in Indian poetic meter) are originated from Sanskrit [2, p. 8]. Meanwhile, of 13,715 words listed in Juynboll's Old Javanese words list, 6,790 are Sanskrit words (49.5\%) [2].

Despite the strong influence of Sanskrit, Gonda claims that the contact between Old Javanese and Sanskrit results in enrichment rather than assimilation[3]. This claim, however, is only based on a calculation of the number of words. In opposition of this, this paper will show that hybridity or assimilations has indeed occurred in Old Javanese.

Both trading and Islamic preaching are the major factors that cause language contact between Arabic and Javanese during the Middle Javanese era. Various aspects of Islamic teachings, especially tasawuf, are among others contained in a type of Middle Javanese literature called suluk. Suluk is a form of Islamic poetry that is composed in the form of traditional Javanese song, macapat, that uses the Javanese language. It is fair, then, to say that suluk is a manifestation of cultural hybrid. In this regard, this paper will demonstrate whether or not the language contact between Arabic and Javanese occurred in the same manner as that between Sanskrit and Javanese.

On the above account, this study tries to examine the hybridity of Javanese culture as reflected in its linguistic hybridity in order to prove the harmony between Javanese and foreign cultures. To this end, lexical and grammatical analysis was performed on Javanese linguistic units borrowed from Sanskrit and Arabic languages.

\section{METHOD}

This study is a qualitative study, because it explores an object that is assumed to be rooted from society or humanity [4, p. 4]. A qualitative study focuses more on the process rather than the product. It involves several steps, including collecting specific data, analyzing the data inductively, and interpreting the meaning of the data [4]. As a qualitative study, this study uses information that comes from a natural setting that, in this case, is gathered from documentations (written texts) of the Old Javanese and the Javanese language. The influence of Sanskrit in Javanese was revealed by examining data taken from an Old Javanese corpus stored on http://sealang.net/ojed/. This web page stores linguistic data of Old Javanese gathered from the Old Javanese English Dictionary [5], that has 25,500 entries; 8,500 of which are original Sanskrit words. The corpus itself contains 105,000 citations from 120 texts. Meanwhile, the influence of Arabic in Javanese was investigated by analyzing the quite popular Suluk Wujil that has been edited by Widyastuti [6].

To facilitate the analysis, the data taken from http://sealang.net/ojed/ was first processed using the corpus and collocates features made available on the web page. 


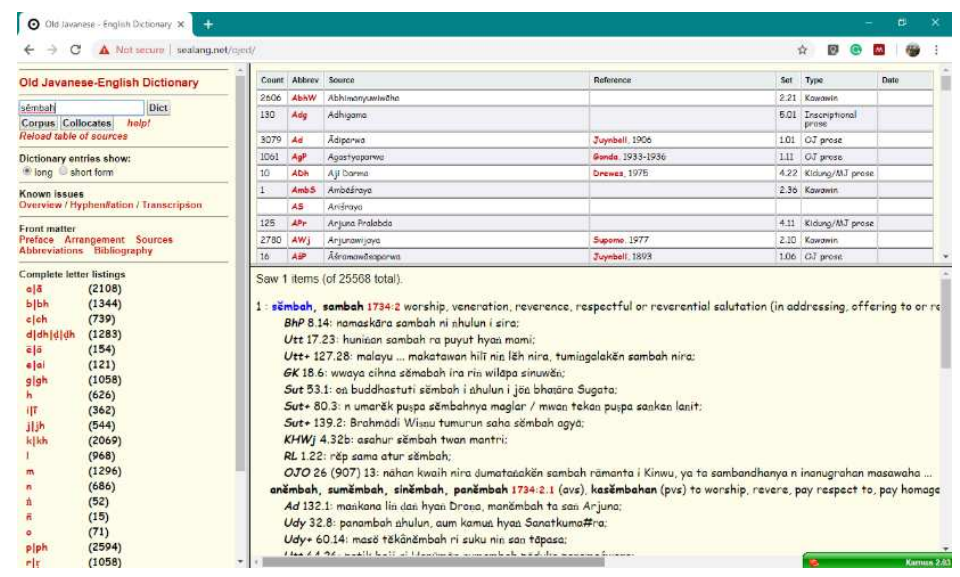

On the other hand, the data taken from Suluk Wujil was processed using the concordance feature on antcont app.

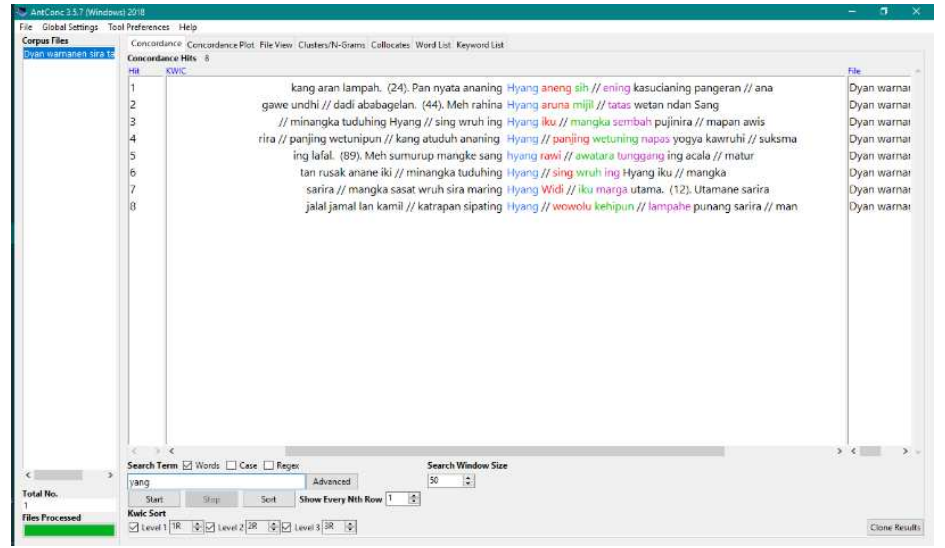

\section{RESULTS AND DISCUSSION}

The analysis will be discussed inductively, starting from the hybridity between Javanese and Sanskrit to the hybridity between Javanese and Arabic.

\subsection{Hybridity between Javanese and Sanskrit}

Javanese Hybridity during the Old Javanese era is seen in some of literatures produced during that era, namely kakawin and parwa. However, as explained by Zoetmulder, the Old Javanese language still maintain its characteristics as an Austronesian language, despite the strong influence of Sanskrit [2]. Words borrowed from Sanskrit are treated as roots in Old Javanese, although in the original language such words have already undergone conjugation. Hybrids between Old Javanese and Sanskrit are formed through grammatical processes undergone by words borrowed from Sanskrit, as seen as follows.

(1) upawāsa 'fasting, abstinence from food, etc. in general' 


$$
\begin{aligned}
& \text { mopawāsa (ma- + upawāsa) 'to fast' } \\
& \text { (2) șaḍpada 'bee' (ṣaḍ 'six', pada 'foot') } \\
& \text { smanaḍpada 'to be or act like a bee' }
\end{aligned}
$$

Both examples above show complex words in which the roots that come from Sanskrit words are paired with affixes that are grammatical elements of Old Javanese. Zoetmulder [2] provides a similar example of Sanskrit word pariwrt 'to turn around' that denotes a passive meaning. This word is borrowed as an Old Javanese word pariwrta and is treated as a root. Consequently, the word pariwrta can be derived into its passive form by adding affix -in- to become pinariwrta and into its active form by adding affix aN- to become amariwrta.

Nonetheless, Sanskrit-borrowed words that have equivalent meaning to original Old Javanese words, such as words that denote feeling like krodha 'angry' do not necessarily undergo a morphological process with affix ma- in order to become verbs [7, p. 120]. Meanwhile, the word gělěng, as an original Old Javanese word that has an equivalent meaning to krodha, has to get affix ma- to become a verb, as seen in the following example.

(3) Magĕlĕng ta bhațāra Brahmā mulati sira 'Bhatara Brahma was angry to see $\operatorname{him} /$ her'.

A similar pattern is also shown in other words that also denote feeling like bhagya 'happy' and sukha 'glad, like'.

Hybridity of Old Javanese is also seen in Sanskrit compound words that are borrowed without changing the word order, such as Yadukula 'Yadu group' and dewaputra 'son of god'. However, their equivalent words in Old Javanese are still retained: watěk Yadu 'Yadu group' and anak hyang 'son of god'. This pattern is also found in other compound words borrowed from Sanskrit.

Parwa, a type of Old Javanese literary work, presents the assimilation between Sanskrit and Old Javanese by citing Sanskrit sentences followed by their translations in Old Javanese in the same sentence, as seen as follows.

(4) Sira ta maweka sang Yadukula, ikang sinangguh watĕk Yadu.

'S/he brought down the Yadukula, which was called Yadu group'

A similar pattern is also found in other compound words originated from Sanskrit, namely sukha 'glad' and dukha 'sad' that are combinations among Sanskrit words kha 'sky', su 'good', and duh 'bad'. Here, the meanings are modified from 'a good sky' to 'glad' (sukha) and 'a bad sky' to 'sad' (dukha).

\subsection{Hybridity between Javanese and Arabic}

The use of Arabic words in Suluk Wujil demonstrates the existence of Javanese hybridity during the Middle Javanese era. A number of words, both those who have and do not have equivalent words in Javanese, are borrowed, especially for the purpose of Islamic preaching. Assimilation between Javanese and Arabic is seen in some Arabic words that actually have equivalent words in Javanese, such as dunya or donya 'world' that is originated from Arabic word dunya: 'world, earth, this world' (as opposed to /a:khira/) [8]. 


\section{(5) yen sira nora weruh // kang sinembah ing dunya iki}

'if you do not know what should be worshiped in this world'

Javanese actually has some words with similar meaning, namely loka, buwana, and jagat that are originated from Sanskrit. The word loka is used in Old Javanese to describe the three realms (triloka), namely the realm of god (heaven), the world of human (world), and the world of monsters and low creatures (lower world). There is also the world jagattraya that also mean the three worlds (traya means 'three'). Still, the word dunya is borrowed because it brings a different concept from what is described by loka, jagat, and buwana. The antonym of dunya in Arabic, akhira, is also borrowed to Javanese with a phonological adjustment becoming akerat. The borrowing of dunya and akerat to Javanese has evidently enrich Javanese vocabulary repertoire.

In Suluk Wujil, an important character is introduced by the name of Ratu Wahdat. This name actually refers to Sunan Bonang, a saint from which the main character, Wujil, learned Islamic teachings. The word wahdat itself comes from Arabic word wahadah that means 'unity'.

(6) Sang Ratu Wahdat mesem ing lathi 'Ratu Wahdat smiled'

(7) Sang Ratu Wahdat lingira aris 'Ratu Wahdat spoke gently'

In Arabic, the word wahdat is commonly followed by other words, such as in wahdatul wujud [9, p. 230]. This term refers to a metaphysical notion comparable to ma'rifat, which in Javanese spiritual tradition is understood as the highest achievement in seeking the nature of God. At this level, there is a unity between a man and the God, because s/he is considered to have found the God by deeply understanding His holiness and wisdom. Therefore, the title wahdat attached to Sunan Bonang reflects his achievement in this spiritual pursuit.

Unlike the hybridity of Javanese during Old Javanese era that results in complex words containing Javanese and Sanskrit elements, language contact between Javanese and Arabic leads to enrichment in Javanese vocabulary, which especially features certain adjustments in the phonological system. The terms nafi nakirah, nafi jinis, and nafi itsbat, for example, are originated from Arabic terms la nafi Jinzi and an-nafyu wa al-Itsbat.

(8) Nafi Nakirah lan Nafi Jinis // mapan iku jinising Pangeran // kang Nafi nyateng Itsbate // Nafi lan Itsbat iku // nora pisah pan ora tunggil // Nafi kalawan Itsbat // Nafi karoni pun // Nafi roro winaleran // dining Illa karone tan kena manjing // maring lafal Illallah.

'Nafi Nakirah and Nafi Jinis constitute the natures of God. Nafi entails Itsbat, Nafi and Itsbat are not separated nor united. (Yet,) Nafi and Itsbat, along with both types of Nafi (Nafi nakirah and Nafi jinis) are restricted by the word Illa and may not and cannot come in to the word Illallah.'

In Arabic, nafi (from the root nafyuu) means 'inexistence'; istbat (from tsabata) means 'acknowledgment' or 'determination'; nakirah means 'uncertainty'; 
and jinis means 'type'. The words nafi and itsbat as seen in example (8) are used to describe the nature of God's existence in Islamic point of view.

Also used in this example is the word illa that is a conjunction in Arabic, forming the word IllaAllah that means 'except God.' Therefore, the concept of godliness as told in Suluk Wujil is characterized by a disacknowledgment towards any types of god and an acknowledgment or istbat that there is no god except God.

\section{CONCLUSION}

Analysis on Javanese hybridity as an effect of Sanskrit and Arabic influence shows that there is a difference between hybridity occurring during Old Javanese era and that occurring during the Middle Javanese era. Thousands of Sanskrit words borrowed to Old Javanese are treated as roots that may undergo certain grammatical processes following the grammatical rules of the Old Javanese language. Consequently, Old Javanese has many complex words that formed from the combination between Sanskrit lexical items and Old Javanese grammatical elements. Not only Sanskrit words, Arabic words are also borrowed to the Javanese language. However, the language contact between Javanese and Arabic tends to lead to vocabulary enrichment, although assimilations also occur, mainly with phonological adjustments. Despite this difference, the hybridity in Javanese, which have been taking place for centuries, reflects a harmony between the Javanese culture and foreign cultures. As a result, Javanese people is nowadays no longer aware of any traces of foreign elements in the Javanese language.

\section{REFERENCES}

[1] S. Mulyani, Sāstra paddhati: merajut ilmu humaniora. Yogyakarta: Penerbit Universitas Sanata Dharma, 2013.

[2] P. J. Zoetmulder, Kalangwan: Sastra Jawa Kuno selayang pandang. Penerbit Djambatan, 1985.

[3] J. Gonda, Sanskrit in Indonesia. Nagpur: International Academy of Indian Culture, 1952.

[4] J. W. Creswell, Research Design: Pendekatan Kualitatif, Kuantitatif, dan Mixed. Yogyakarta: Pustaka Pelajar, 2010.

[5] P. J. Zoetmulder and S. O. Robson, Old Javanese-English Dictionary. Dordrecht: Springer Netherlands, 1982.

[6] S. H. Widyastuti, Suluk wujil: suntingan teks dan tinjauan semiotik, 1st ed. Semarang: Kelompok studi Mekar, 2001.

[7] D. Puspitorini, “Afik Verbas Bahasa Jawa Kuno,” Universitas Indonesia, 2015.

[8] H. Wehr, A Dictionary of Modern Written Arabic, Arabic-English. London: McDonald \& Evans Ltd., 1974.

[9] S. Endraswara, Falsafah hidup Jawa. Yogyakarta: Cakrawala, 2003. 